\title{
Editorial
}

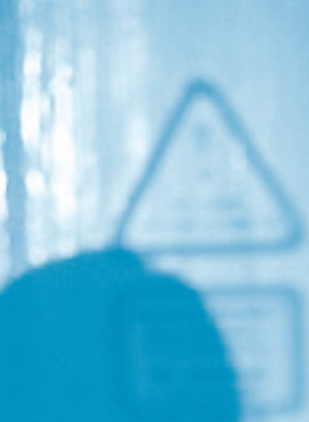

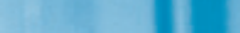

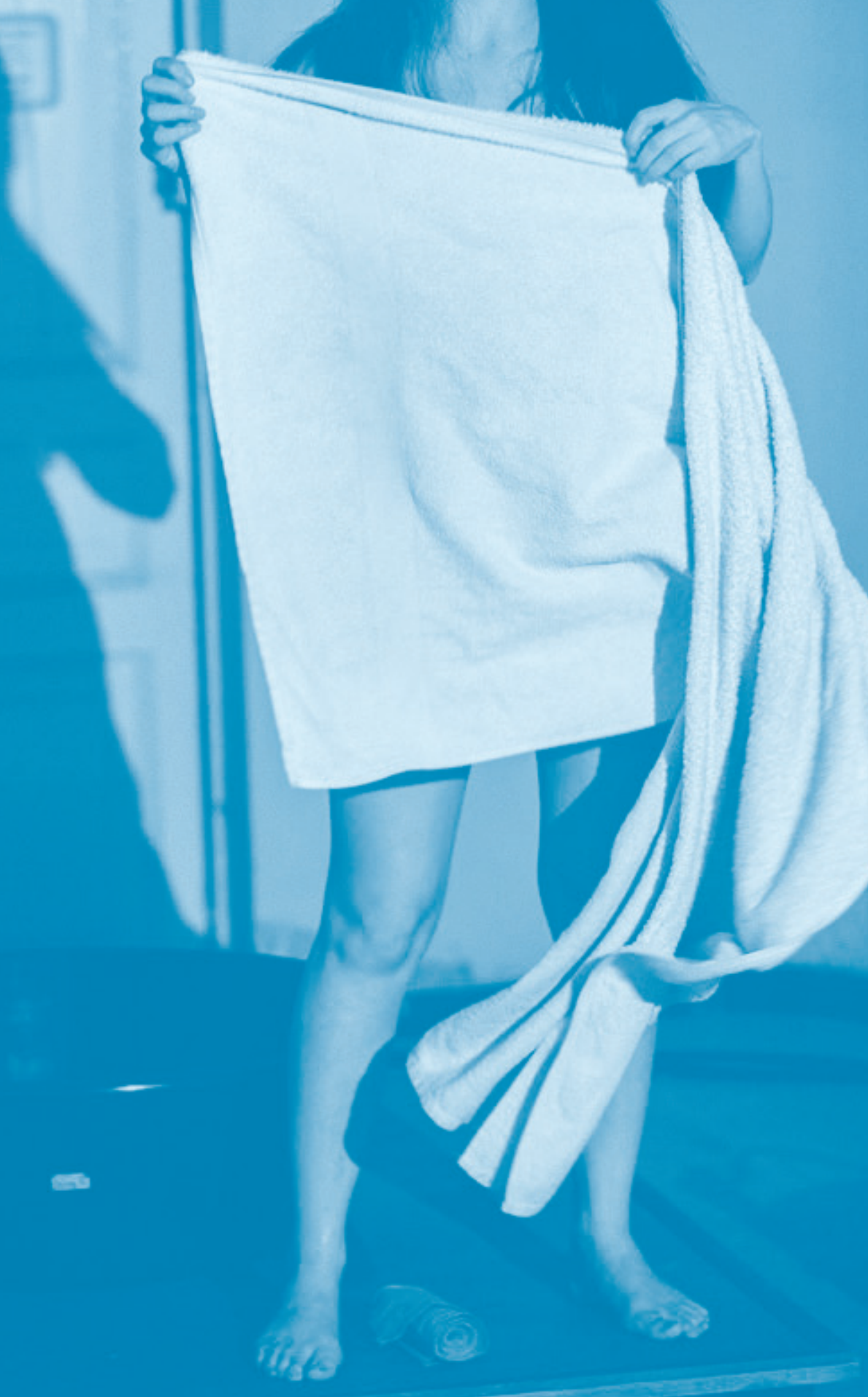




\section{No hay quinto malo y no es un toro}

\author{
Pedro Pablo Gómez Moreno \\ Universidad Distrital Francisco José de Caldas \\ ppgomezm@udistrital.edu.co
}

Cómo citar este artículo: Gómez, Pedro Pablo. (2018). No hay quinto malo y no es un toro. Estudios Artísticos: revista de investigación creadora, 4(5) pp. 170-172: DOI: https://doi.org/ $10.14483 / 25009311.13491$

Rompe cabeza (2017). Dir. Antonio Zuñiga. Complejo Ho. Fotografía: Carlos Mario Lema
Llegamos al número cinco de Estudios Artísticos, emocionados por haber conseguido hasta la fecha publicar más de cuarenta artículos de interés. En este año (2018) hemos cambiado la periodicidad de la revista de anual a semestral como resultado de la confianza que los autores depositan en este proyecto editorial. Por otra parte, contamos ya con tres indexaciones internacionales: en La Red Iberoamericana de Innovación y Conocimiento Científico-REDIB, en el Directory of Open Acces Journal -DOAJ y en Actualidad Iberoamericana. Al mismo tiempo, nos preparamos para participar en la próxima convocatoria de PUBLINDEX en Colombia. Todo esto, unido a ajustes evidentes en el formato de nuestra versión impresa y configuración del equipo editorial, nos da la confianza suficiente para seguir trabajando en el posicionamiento académico de Estudios Artísticos: revista de investigación creadora, en el panorama de las revistas especializadas que piensan el arte desde el Sur Global.

Abrimos este número con el artículo de nuestro autor invitado, Jacques Rancière, quien se ocupa de repensar la modernidad estética para mostrar que esto conduce a una política. Esta política inspirada en el régimen estético, como política de indeterminación y de libertad, da origen a la idea de una política propiamente estética, de un comunismo estético en el que hay comunicación directa entre las formas del arte y de la vida. Enseguida, Angélica González, tomando elementos esenciales de la reflexión del filósofo francés, Jacques Rancière, indaga por la posibilidad de pensar el "nudo" polémico por el cual arte y política, desde su especificidad, redistribuyen lo "sensible" de una comunidad haciendo visibles los sujetos y objetos que antes no eran contados como partes. Luego, 
Bruno Mazzoldi, desde el análisis de dos obras del artista Jeisson Castillo, nos hace sospechar de los lasos de sujetos soberanos que pretenden no solo reconciliar a los maestros de la Amazonía con la modernidad de la postmodernidad, sino también asimilar las luchas por la transformación comunitaria emancipadora con las luchas por la inclusión social. Más adelante, Pablo Alejandro Suárez Marrero, se propone allanar la brecha que existe entre los abordajes tradicionales del discurso musical y los estudios del performance, de tal manera que se pueda traducir en términos musicales, interpretativos, expresivos y performativos los datos que obtiene de la realización de un determinado y contextualizado análisis musical. Enseguida, Pedro Pablo Gómez, dialoga con Irene Gómez para ofrecernos un panorama de la escena local de la guitarra clásica y un recorrido por algunos de los acontecimientos más relevantes de su carrera musical como una de las más reconocidas guitarristas clásicas de Colombia.
Por su parte, Ludmila Brandão y Suzana Guimarães, se ocupan de mostrar cómo el artista plástico Alcides Pereira dos Santos, hace de la iconografía del libro didáctico un particular medio para experimentar el sentido desconcertante del lenguaje. El artista además toma las imágenes como materia para su propio mundo "mezclado" alejándose así de la imagen moderna occidental. Para cerrar este número de la revista, David Franco Colorado, se ocupa del análisis de dos obras de la artista Remedios Varo para pensar su práctica como surrealista y femenina al mismo tiempo, en los intersticios del inconsciente individual y el inconsciente colectivo del mundo capitalista.

Así, estimado lector, no me queda más que invitarle al recorrido in extenso por los pensamientos $y$ conocimientos sensibles que están presentes en cada uno de los artículos de la revista. 